\title{
SENTIMENT ANALYSIS OF THE COMMUNITY IN THE TWITTER TO THE 2020 ELECTION IN PANDEMIC COVID-19 BY METHOD NAIVE BAYES CLASSIFIER
}

\author{
Akhmad Muzaki*1, Arita Witanti ${ }^{2}$ \\ ${ }^{1,2}$ Teknik Informatika, Fakultas Teknologi Informasi, Universitas Mercu Buana Yogyakarta, Indonesia \\ Email: ${ }^{1}$ akhmadmuzaki713@gmail.com, ${ }^{2}$ arita.mercu-buana@yogya.ac.id
}

(Naskah masuk: 09 Januari 2021, diterima untuk diterbitkan: 12 Februari 2021)

\begin{abstract}
The 2020 regional elections in the midst of the COVID-19 pandemic are starting to get crowded starting from the real world and in cyberspace, especially on Twitter social media. Twitter's existence has been widely used by various communities in recent years. Twitter is one of the media that represents the public response regarding public issu. Ahead of the general election (PEMILU), there are usually some parties who want to know the results of public sentiment or response to the issue, namely academics, intellectuals or even political opponents. Nevertheless, the implementation of local elections is very polemic in the community, therefore this study tries to analyze tweets that talk about issue public, namely the 2020 elections in the wake of the COVID-19 Pandemic. The analysis usually uses the classification of tweets containing public sentiment about the issue. The classification method used in this research is Naive Bayes Classifier (NBC) And Support Vector Machine (SVM). Naive Bayes Classifier is combined with features that can detect weighting using probability. The classification of tweets in this study was obtained based on a combination of two classes namely sentiment class and category class. The classification of sentiment consists of positive and negative. Test results on built-in applications show that accuracy with Naive Bayes delivers better results than Support Vector Machine. However, overall the use of the Naive Bayes method has a good performance to classify tweets with an accuracy rate of $92.2 \%$
\end{abstract}

Keywords: classification, Naive Bayes Classifier, sentiment analysis.

\section{SENTIMEN ANALISIS MASYARAKAT DI TWITTER TERHADAP PILKADA 2020 DITENGAH PANDEMIC COVID-19 DENGAN METODE NAÏVE BAYES CLASSIFIER}

\begin{abstract}
Abstrak
Pemilihan kepala daerah (Pilkada) serentak 2020 di tengah pandemic COVID-19 mulai ramai di bicarakan mulai dari dunia nyata maupun di dunia maya, khususnya di media sosial Twitter. Keberadaan Twitter telah digunakan secara luas oleh berbagai kalangan masyarakat dalam beberapa tahun terakhir. Twitter adalah salah satu media yang merepresentasikan tanggapan masyarakat terkait issu publik. Menjelang dilaksanakanya pemilihan umum (PEMILU), biasanya ada beberapa pihak yang ingin mengetahui hasil sentimen atau tanggapan masyarakat terhadap issu tersebut, yaitu akademisi, intelektual atau bahkan lawan politik. Kendati demikian pelaksaan pilkada sangat menuai polemik di lapisan masyarakat,oleh karena itu penelitian ini mencoba menganalisis tweet yang membicarakan tentang issu public yaitu pilkada 2020 di tengan Pandemic COVID-19. Analisis yang dilakukan biasanya menggunakan klasifikasi tweet yang berisi sentimen masyarakat tentang issu tersebut. Metode klasifikasi yang digunakan pada penelitian kali ini adalah Naive Bayes Classifier (NBC) Dan Support Vector Machine (SVM). Naive Bayes Classifier dikombinasikan dengan fitur yang dapat mendeteksi pembobotan menggunakan probabilitas. Klasifikasi tweet dalam penelitian ini diperoleh berdasarkan kombinasi antara dua kelas yaitu kelas sentimen dan kelas kategori. Klasifikasi sentimen terdiri dari positif dan negatif. Hasil pengujian pada aplikasi yang dibangun memperlihatkan bahwa akurasi dengan Naive Bayes memberikan hasil yang lebih baik dari pada Support Vector Machine. Namun demikian, secara keseluruhan penggunaan metode Naive Bayes memiliki performansi yang baik untuk melakukan klasifikasi tweet dengan tingkat akurasi 92,2\%.
\end{abstract}

Kata kunci: analisis sentimen, klasifikasi, Naive Bayes Classifier.

\section{PENDAHULUAN}

Pemerintah melalui Perpu nomor 2 tahun 2020 mengenai pemilihan kepala daerah diselenggarakan pada 9 Desember 2020. Pilkada 2020 diselenggarakan pada 23 September untuk pemilihan sembilan gubernur 224 Bupati dan 37 walikota secara serentak. Sebelum Indonesia terpapar COVID-19 
komisi pemilihan umum (KPU) telah melaksanakan beberapa tes tahapan pelaksanaan Pilkada serentak 2020 namun akibat wabah COVID-19 akhirnya komisi pemilihan umum mengeluarkan surat keputusan KPU Nomor.179/PL.02.Kpt/01/KPU/III/2020. Yang akhirnya mengundang kontroversial serta polemik dikalangan intelektual, akademisi juga masyarakat pada umumnya sebab bagaimana mungkin tetap dilaksanakan Pilkada sedangkan angka penyebaran COVID-19 masih sangat tinggi[1].

Media sosisal Twitter dan Facebook bersaing ketat dalam merangkul jumlah penggunanya di Indonesia. Kendati demikian, pengguna kedua platfrom tersebut memang merupakan pasar yang penting. Berdasarkan data PT Bakrie Telecom, memiliki angka 19,5 juta pengguna aktif Twitter di Indonesia dari total 500 juta pengguna Twitter di dunia. Twitter adalah salah satu jejaring sosial terbesar di dunia yang mampu meraup keuntungan yang sangat besar yaitu mencapai nilai $U S D 145$ juta. Jumlah tersebut tentu saja sudah bertambah hingga Sepember 2020 ini. Selain itu, Indonesia menempati urutan kelima pengguna Twitter terbanyak setelah Negara USA, Brasil, Jepang, dan UK [2]. Dalam media sosial Twitter sekita 1.200 tweet pada tanggal 20 Oktober 2020 menyuarakan tentang permasalahan dalam Pilkada serentak yang akan dilaksanakan pada bulan Desember 2020. Dalam media Twitter secara tidak langsung kita bisa melihat suara rakyat tentang pilkada 2020. Berikut adalah data pengguna Twitter di Indonesia yang ditampilkan pada gambar 1, dimana data pengguna mengalami peningkatan pada tahun ke tahun.

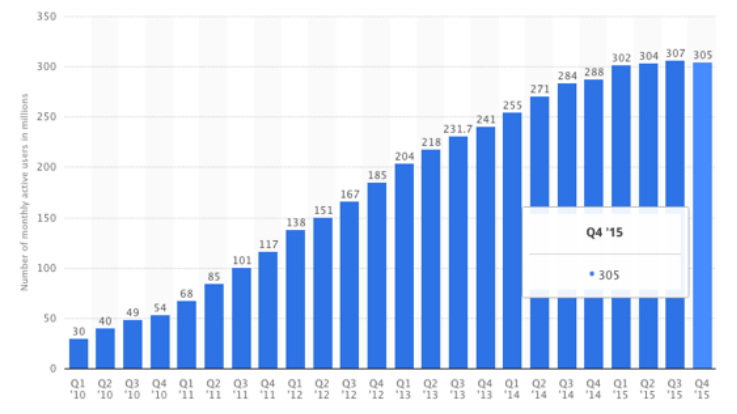

Gambar 1. Data Pengguna Twitter [3]

Ketika berkunjung ke Indonesia, bulan Oktober 2015, CEO Facebook yaitu Mark Zuckerberg mengatakan bahwa Indonesia merupakan pasar yang potensial. Twitter sering digunakan untuk menggali informasi yang berharga dan kelebihan penggunaan yang mudah. Salah satu fitur yang paling banyak digunakan adalah tweet, akan menjadi sangat sia-sia jika tidak dimanfaaatkan dengan benar, sehingga dibutuhkan teknik yang mampu mengolah tweettweet tersebut sehingga nantinya menghasilkan informasi yang berharga.
Sentimen analisis merupakan suatu bidang studi yang mampu menganalisis opini dari seseorang, sentimen, evaluasi, perilaku dan emosi seseorang melalui entitas seperti layanan umum, organisasi, issu, kejadian, topik dan atribut-atribut lainya. Sebagian besar sentimen analisis banyak digunakan untuk kepentingan politik, ekonomi, bisnis, pendidikan atau pemerintah dalam menganalisis opini masyarakat atas suatu kejadian sehingga kebijakan yang dibuat mampu menyasar sampai ke bagian akar dan rumput. Sentimen analisis dalam dunia bisnis kebanyakan digunakan untuk menganalisis tren. atau kebutuhan pasar, atau kebutuhan masyarakat yang diharapkan dapat menyusun strategi pemasaran yang tepat dan dapat meningkatkan pendapatan perusahaan mereka[2].

Tahun 2020 merupakan periode akhir masa jabatan kepada daerah, sehingga perlu diselenggarakan pemilihan kepala daerah (Pilkada) periode 2020-2025. Pada Pilkada ini terdapat pasangan cagub (calon gubernur) beserta cawagub (calon wakil gubernur). Dalam pra-pelaksanaan maupun pelaksan Pilkada terdapat berbagai opini dan tanggapan dengan sentimen positif dan negatif pada media sosial maupun di dunia nyata terkait diselenggarakanya Pilkada serentak 2020, Pemilih akan sangat beresiko tertular COVID-19 jika pemerintah tetap melaksanakanya. Permasalahan yang muncul adalah ketika pemerintah menghimbau agar masyarakat tetap dirumah namun disisi lain pilkada harus tetap dilaksanaan. Tujuan penelitian ini dimaksudkan untuk mengetahui sentiment masyarakat terhadap pelaksanaan pilkada 2020 yang akan dilaksanakan pada tanggal 9 Desember dan ditengah pandemic COVID-19 dengan menggunakan metode Naïve Bayes Classifier.

\section{METODE PENELITIAN}

Penelitian ini menggunakan metode Naive bayes classifier karena dalam proses klasifikisi dan perhitungan probabilistik, naive bayes memiliki lebih banyak keunggulan. Salah satu keunggulanya adalah pengklasifikasian statistik yang dapat digunakan untuk memprediksi probabilitas. Naive Bayes berdasarkan pada teorema Bayes yang memiliki kemampuan untuk mengklasifikasi yang sama dengan decision tree dan neural network. Naive Bayes terbukti memiliki tingkat akurasi dan kecepatan yang tinggi ketika diaplikasikan ke dalam database dengan data yang sangat besar[4].

\subsection{Text Mining}

Text mining adalah bagian dari data mining dimana proses yang dilakukan adalah melakukan ekstraksi pengetahuan dan informasi dari pola-pola yang terdapat dalam sekumpulan dokumen text menggunakan alat analisis tertentu. Text mining dapat juga dimanfaatkan menjadi beberapa macam kebutuhan diantarannya yaitu untuk summarization, 
pencarian dokumen teks dan sentiment analisis[2]. Text mining berfungsi untuk mencari dan mematerialkan kata-kata yang dapat mewakili apa yang ada didalam dokumen sehingga dapat dilakukan analisa keterhubungan antar dokumen. Text mining mempunyai 4 tahapan yaitu Tokenizing, Filtering, Stemming, dan Analyzing.

Tahapan tokenizing merupakan proses pemotongan string masukan berdasarkan tiap kata yang menyusunnya. Pada dasarnya proses ini ialah memisahkan setiap kata yang menyusun suatu dokumen. Tahapan Filtering merupakan suatu proses dimana data diambil sebagian dari data tertentu, dan membuangnya pada frekuensi yang lain. Tahapan Stemming adalah proses dimana pemetaan atau penguraian berbagai bentuk teks dari sebuah kata menjadi bentuk kata dasarnya. Tahapan Tagging adalah metode yang belum lama dilahirkan. Dahulu sebelum ditemukanya metode tagging, data informasi yang beredar di internet berantakan dan tidak tersusun dengan rapih berdasarkan kategorinya. Tahapan Analyzing adalah tahapan untuk mencari seberapa jauh keterhubungan data antar kata-kata disetiap dokumen.

\subsection{Sentimen Analisis}

Sentimen analisis merupakan salah satu bidang studia tau metode yang fungsinya menganalisis opini masyarakat, sentimen, evaluasi, penilaian, perilaku dan emosi melalui entitas seperti produk, layanan umum, organisasi, individual, issu, kejadian dan topik. Sentimen analisis berfokus kepada opini yang mengandung pesan negatif atau positif [2]

Proses data mining terbentuk dari beberapa tahapan, salah satunya adalah pengumpulan data data collection, data transformation, dan data analysis [4]. Proses tersebut dimulai melalui pre-processing yang terbentuk dari pengumpulan data untuk menghasilkan data mentah (raw data) yang akan dibutuhkan oleh data mining, yang kemudian dilanjutkan dengan proses transformasi data untuk mengubah data mentah berubah menjadi format yang lebih mudah diproses oleh data mining, misalnya melalui filtrasi atau agregasi. Selanjutnya hasil transformasi data akan di manfaatkan oleh analisis data untuk membangkitkan pengetahuan dengan menggunakan teknik seperti analisis statistik, machine learning [7], dan visualisasi informasi.

\subsection{Klasifikasi}

Klasifikasi tergolong dalam area pembelajaran machine learning dimana mesin mempelajari data yang sudah diberi label atau data yang sudah terklasifikasi. Terdapat beberapa algoritma yang potensial digunakan dalam klasifikasi sentimen misalnya adalah Naive Bayes, $K-N N$, Logistic Regression, Support Vector Machine, Artificial Neural Network dan lain-lain[8].

\subsection{Naive Bayes Classifier}

Naive Bayes adalah klasifikasi linear yang sangat efisien. Model probabilitas dan klasifikasi Naive Bayes didasarkan atas teorema bayes, dan adjective naive berasal dari asumsi yaitu fitur yang ada pada dataset saling independen. Model probabilitas yang telah diformulasikan oleh Thomas Bayes (1701-1761) [2] sangat sederhana berikut adalah formulasinya:

posterior probability $=$

$\frac{\text { conditional probability.prior probability }}{\text { evidence }}$

Notasi umum dari posterior probability juga bisa dituliskan seperti berikut

$P\left(Y_{j} \mid X_{i}\right)=\frac{P\left(Y_{j} \mid X_{i}\right) \cdot P\left(Y_{j}\right)}{P\left(X_{i}\right)}$

Di mana :

$X_{i} \quad=$ fitur sampel Vector $i, i €\{1,2, \ldots, n\}$

$Y_{j} \quad=$ notasi kelas $j, j €\{1,2, \ldots, m\}$

$P\left(Y_{j} \mid X_{i}\right)=$ probabilitas dari sampel $X_{i}$ milik kelas $W_{j}$.

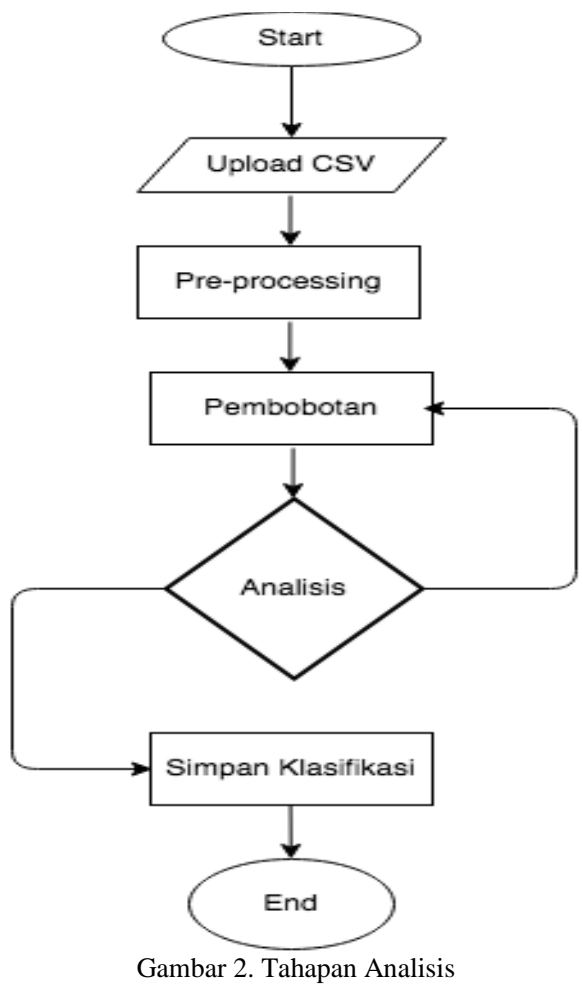

Pada proses ini data yang sudah melewati proses pre-processing dengan baik akan dilanjutkan dengan pembobotan [9]dan akan diberikan algoritma Naive Bayes. Proses pembelajaran akan dilakukan dengan data yaitu data latih. Data latih merupakan data yang sudah mempunyai label positif dan negatif, sebagai pembelajaran untuk mengetahui label dari suatu dokumen. Jumlah keseluruhan data adalah 1200 data dengan pembagian data latih dan data uji. Perbandingkan antara data latih dan data uji adalah sebanyak $70 \%$ untuk data latih dan $30 \%$ untuk data 
uji. Data latih dan data uji akan sama-sama diimplementasikan menggunakan algoritma Naive Bayes. Adapun tahapan analisis diunjukan pada gambar 2.

\subsection{Pre-processing}

Pre-processing adalah tahapan yang paling penting dalam proses text mining, tahapan ini adalah tahap pertama dalam pemrosesan text. Pada tahapan ini text akan dinormalisasikan sehingga nantinya dapat memudahkan pada tahap pembobotan. Preprocessing dilakukan untuk menghindari data yang kurang sempurna atau cacat, atau data-data yang tidak konsisten [2]. Tahapan text pre-processing Pada penelitian ini diantaranya ditunjukan pada tabel 1 .

\begin{tabular}{cc}
\multicolumn{2}{c}{ Table 1. Pre-processing } \\
\hline Sebelum & Sesudah \\
\hline Tetap gunakan hak pilih & Tetap gunakan hak pilih \\
andam, tapi jangan lupa & andam, tapi jangan lupa \\
disiplin mematuhi protokol & disiplin mematuhi protokol \\
kesehatan. Pilkada te... & kesehatan. Pilkada \\
https://t.co/RWRvnlTCY & \\
\hline
\end{tabular}

1. Menghapus $U R L$

Url (http://www.situsname.com) dan email nama (nama@situs.com)

2. Mengganti Emoticon

Pada proses convert emoticon adalah mengganti emoticon yang ada pada tweet berupa kata yang mencerminkan emoticon. Daftar konversi emoticon dapat dilihat pada tabel 2:

Table 2. Konversi Emoticon

\begin{tabular}{cc}
\hline Emoticon & Konversi \\
\hline$:):-):()):-))=))$ & Senyum \\
$: D:-D=D$ & Tawa \\
$:-(:($ & Sedih \\
$:-):)$ & Kedip \\
$:-P: P$ & Ejek \\
$:-/: /$ & Ragu \\
$:::-1$ & Haru \\
\hline
\end{tabular}

\section{Case Folding}

Tahapan ini adalah tahap dimana case folding akan mengubah semua huruf yang ada pada dokumen menjadi bentuk yang sama seperti mengubah semua dokumen ke bentuk lower case [10].

4. Remove number or Puntuation

Tahapan ini adalah tahapan dimana dokumen dihilangkan nomor dan tanda baca yang di dalam teks.

5. Stopwords

Stopwords atau kata sambung yaitu katakata yang sangat sering dipakai dalam Bahasa Indonesia. Contoh stopwords dalam bahasa Indonesia antara lain "saya", "anda", "dia", dan "kita". Stopwords bisa dihilangkan sebab terkadang kata-kata tersebut terdapat hampir di setiap tweet yang ada dengan demikian, menghilangkan stopwords tidak akan berpengaruh apapun pada tahap pelatihan model[11].

6. Tokenizing

Tahapan ini merupakan tahapan membagi kalimat ke dalam beberapa token[12] contoh kalimat "Tolak Pilkada 2020" setelah dilakukan tokenisasi akan menjadi "Tolak" "Pilkada" "2020".

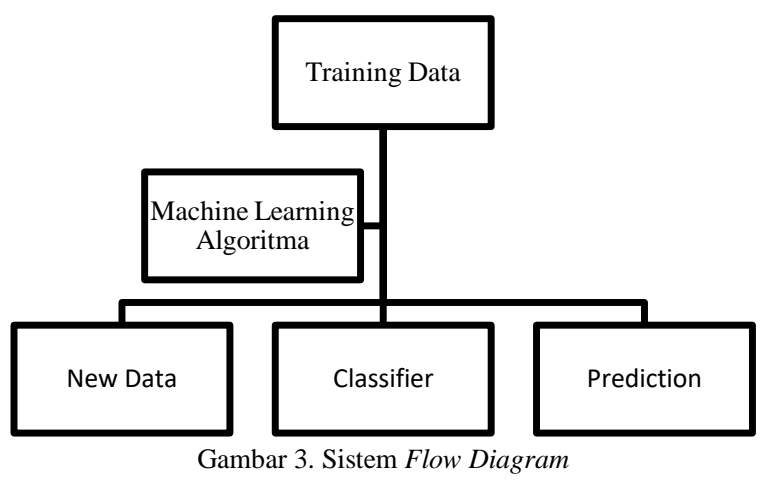

Sistem Flow Diagram merupakan bagan yang menunjukkan aliran atau arus dokumen dari satu tahap ke tahap selanjutnya di dalam sistem secara logika, dan dapat menggambarkan tiap-tiap bagian[13] yang ditunjukan pada gambar 3 .

\subsection{Desain}

Tahap desain yang dilakukan adalah, diagram activity, dan perancangan antar muka.

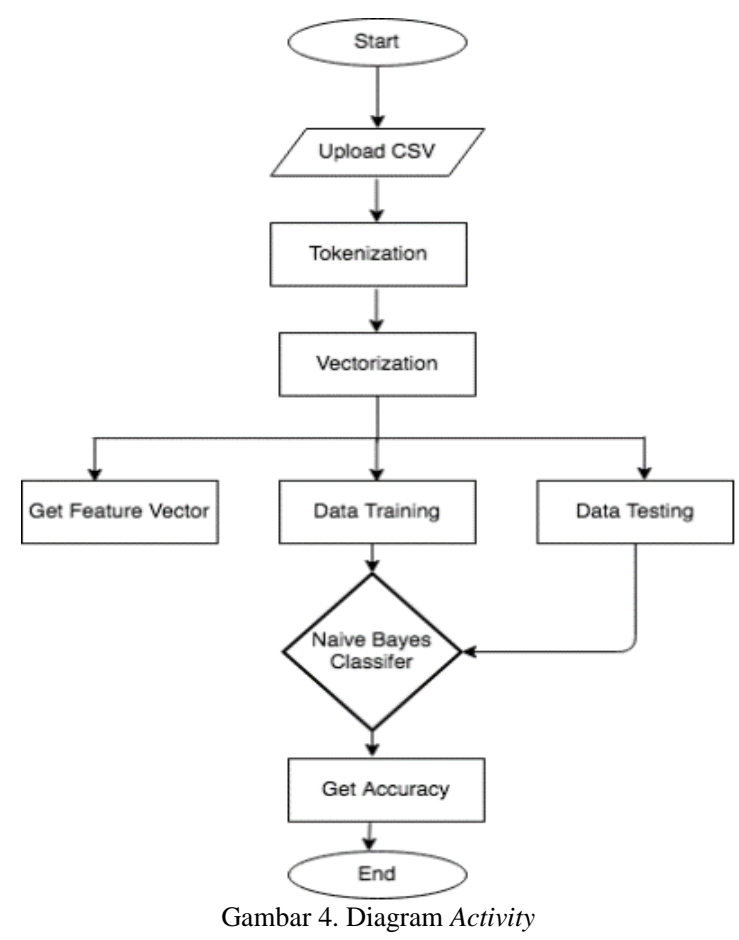


Activity diagram adalah tipe diagram khusus dari statechart yang berfokus pada sebuah aktivitas atau rangkaian proses yang sesuai dengan metode atau fungsi aktivitas yang telah terjadi. Adapun activity diagram ditunjukan pada Gambar 4[14].

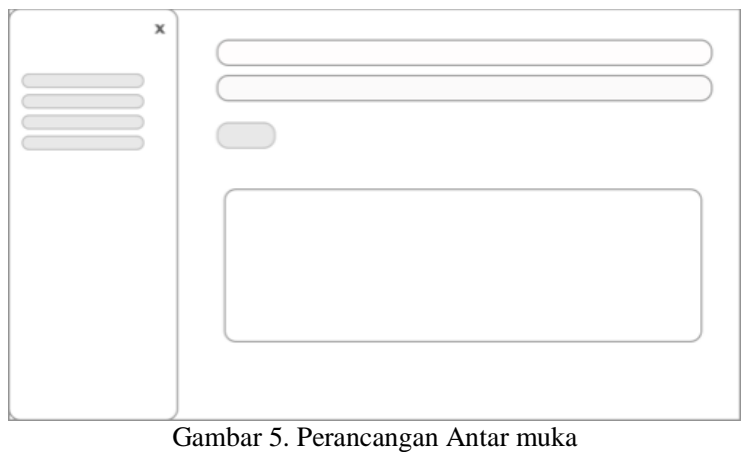

Pada perancangan antar muka atau user interface dimaksudkan agar supaya user dapat mengerti dengan mudah isi konten pada aplikasi web tersebut yang ditunjukan pada gambar 5 .

\subsection{Kerangka Berfikir}

Berikut adalah gambar dari proses kerangka berfikir dari aplikasi yang di bangun. Mulai dari klasifikasi hingga hasil akhir apakah masyarakat menyetujui pelaksanaan pilkada atau malah sebaliknya yang ditunjukan pada gambar 6 .

Klasifikasi komentar masyarakat di twitter mengenai pilkada 2020 untuk mengetahui sejauh mana pro dan kontra.

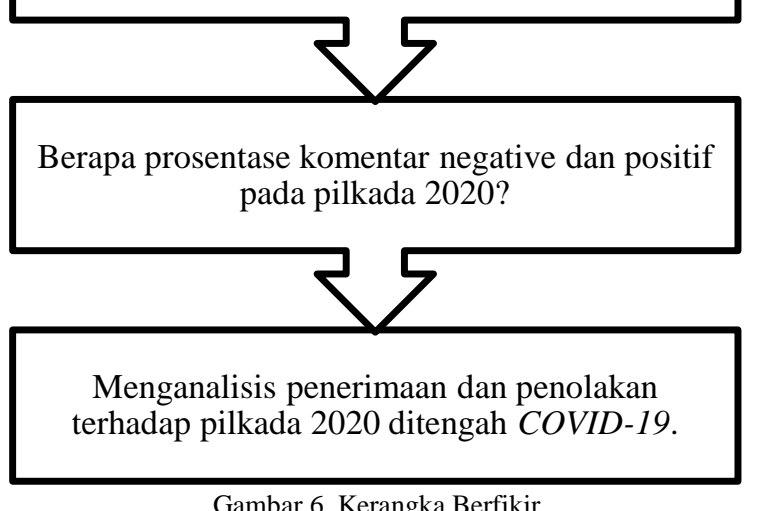

\subsection{Implementasi}

Sentimen analisis berbasis web yang bertujuan untuk mengetahui persentasi positif dan negatif terkait pelaksanaan Pilkada 2020 akan dibangun dengan menggunakan bahasa pemrograman (PYTHON) [14] adalah bahasa pemrograman umum yang ditafsirkan tingkat tinggi. Dibuat oleh Guido van Rossum, dengan framework Streamlit. Streamlit merupakan pustaka dari python sumber terbuka (open source) yang mampu mengubah skrip menjadi aplikasi web yang dapat ditampilkan dalam beberapa menit. Ini membuatnya sangat mudah untuk membangun sebuah aplikasi web khususnya untuk mereka yang memiliki sedikit pengetahuan tentang kerangka kerja desain front-end.

\subsection{Pengujian}

Dalam penelitian ini akan dilakukan pengujian dengan menggunakan metode Naive Bayes Classifier. Pengujian dengan metode Naive Bayes digunakan untuk mendapatkan sentiment probability dalam suatu perangkat lunak, sedangkan mengukur akurasinya menggunakan NMF Vector (Non-negatif Matriks Faktorisasi)[15]. adalah sekelompok algoritma di analisis multivariat dan aljabar linear di mana matriks $\mathrm{V}$ yang di faktorkan ke dalam (biasanya) dua matriks $\mathrm{W}$ dan $\mathrm{H}$, dengan properti bahwa ketiga matriks tidak memiliki elemen negatif. Non-negativitas ini membuat matriks yang dihasilkan lebih mudah diperiksa dioperasikan dengan benar[16].

\section{Hasil Dan Pembahasan}

Dalam penelitian ini akan dilakukan implementasi dari hasil perancangan sistem serta perangkat lunak yang dibuat. Implementasi ini menjelaskan mengenai bentuk interface dari Aplikasi Sentimen Analisis yang telah di buat dengan framework streamlit.

\subsection{Halaman Hompage}

User pada halaman ini dapat memasukan data dan mengelola dataset, melakukan data analis, Tokenization, Vectorization dan Modeling yang ditunjukan pada gambar 7 .

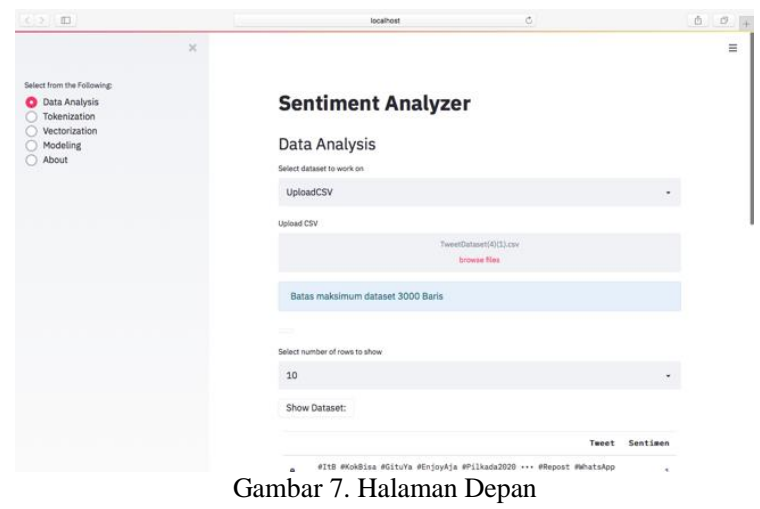

Pada halaman gambar 7, menunjukan dataset yang diambil dari Twitter menggunakan Twitter API. Data yang di dapat sebanyak 1200 tweet yang ditunjukan pada gambar 8 .

Pada halaman dataset dibersihkan dari lowercase dan huruf alpha tanda kutip dan lain-lain contoh "Tolak" "Pilkada" "2020" menjadi Tolak Pilkada 2020 dan ditunjukan pada gambar 9. 


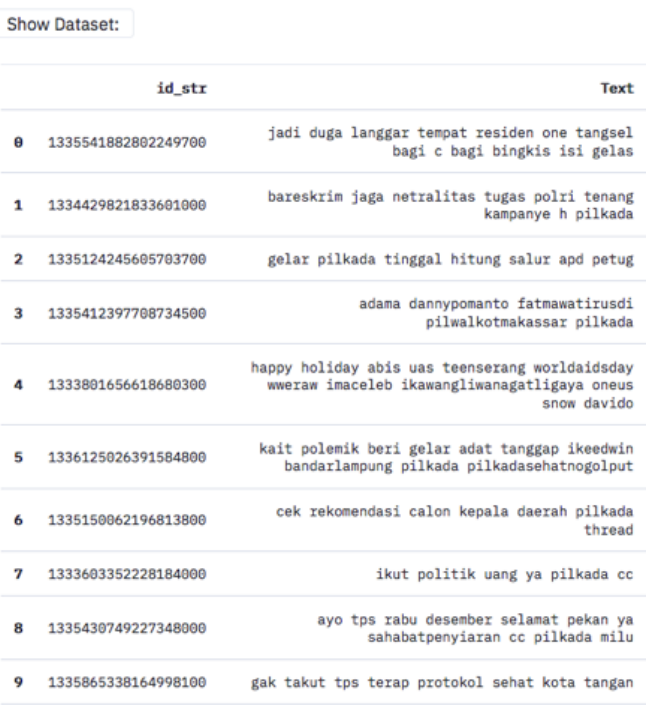

Gambar 8. Dataset

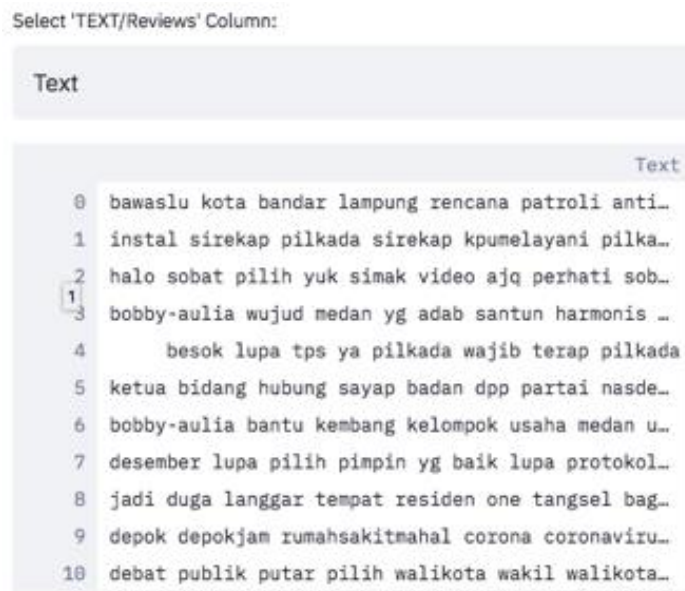

Gambar 9. Halaman Tokenization

Show Top Words:

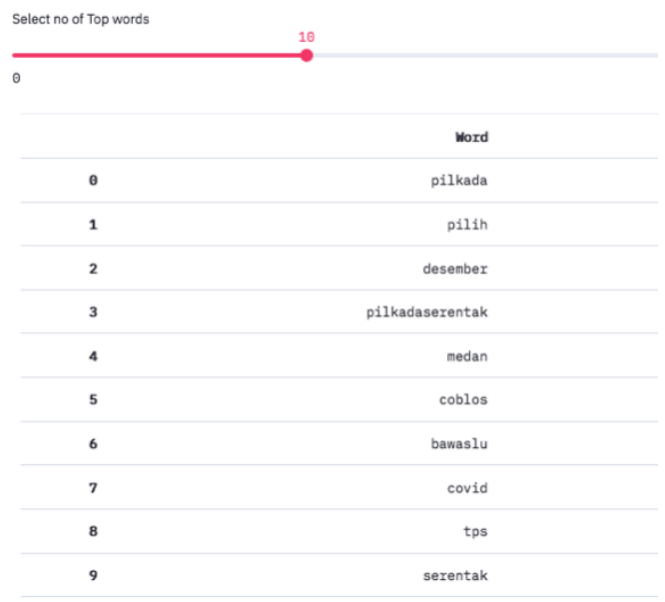

Gambar 10. Vectoeization Top Words

Pada hamalan gambar 10 , dataset di cari katakata teratas atau terbanyak yang di tweet oleh masyarakat. Untuk setiap kata atau fitur yang dimiliki tweet-tweet tersebut pada selang waktu tertentu akan dihitung nilai $T f . I d f$-nya. Setelah itu diambil beberapa kata atau fitur yang memiliki nilai tertinggi. Hasil akhir dari sistem ini adalah kata atau term yang memiliki nilai paling tinggi yang nantinya akan merepresentasikan topik pemicu nilai sentimen pada tweet tersebut yang ditunjukan pada gambar 10 .

Dimana

$$
W_{x, n}=T f I d f_{x, n}+a w_{x, n-1}
$$

$W_{x, n} \quad=$ Bobot kata $\mathrm{x}$ pada interval ke- $\mathrm{n}$

$T f I d f_{x, n}=$ Nilai Tf-Idf kata x pada interval ke-n

$\alpha=$ Discounted comulative factor

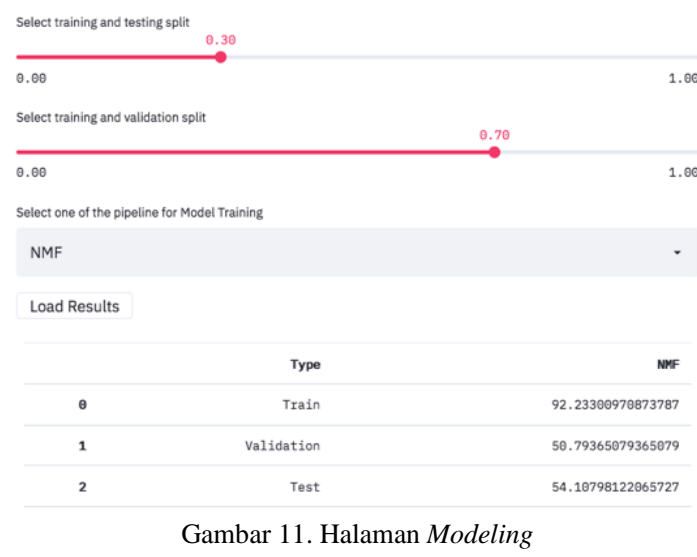

Pada hamalan ini dataset dibagi menjadi dua yaitu data tranie dan data uji dengan masing-masing perbandingan $70 \%$ dan $30 \%$. Yang menghasilkan nilai akurasi 92,2\%. maka dengan penggunaan algoritma Naive Bayes Classifier untuk melakukan proses klasifikasi sangat tepat karna menghasilkan jumlah akurasi data yang tinggi yang ditunjukan pada gambar 11 dan 12.

$$
\text { Akurasi }=\frac{\mathrm{TP}+\mathrm{TN}}{T P+F P+T F+F N}
$$

\begin{tabular}{rrr}
\hline \multicolumn{3}{c}{ Type } \\
\hline $\boldsymbol{\theta}$ & Train & 92.23300970873787 \\
\hline $\mathbf{1}$ & Validation & 50.79365079365079 \\
\hline $\mathbf{2}$ & Test & 54.10798122065727 \\
\hline
\end{tabular}

Gambar 12. Nilai Accuracy Data

Pada hamalan ini menunjukan hasil sentiment masyarakat dimana 0 adalah positif dan 1 adalah negatif, maka dari hasil sentiment berikut ini menunjukan bahwa lebih dari $50 \%$ data yang saya ambil menunjukan hasil sentiment negatif yang ditunjukan pada gambar 13 . 


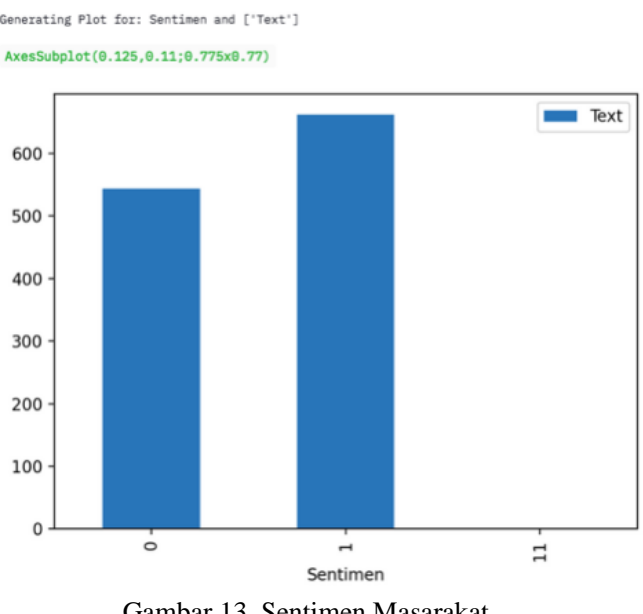

Gambar 13. Sentimen Masarakat

\section{KESIMPULAN}

Dari penelitian yang telah dilakukan, maka kesimpulan bahwa analisis sentimen dapat digunakan untuk mengetahui sentimen masyarakat khususnya Netizen Twitter terhadap pelaksanaan pilkada 2020 ditengah pandemik COVID-19. Setelah dilakukan analisis sentimen, terlihat berapa banyak sentimen yang ditujukan kepada hastag pilkada2020. Jika di lihat dari hasil data yang ditunjukan di atas maka ada baiknya pemerintah menunda pelaksanaan Pilkada dikarnakan adanya pandemik sehingga masyarakat dapat memilih calon yang bermutu dengan tenang serta gembira tanpa adanya ketakutan akan tertular COVID-19.

\section{DAFTAR PUSTAKA}

[1] F. D. Anisa, "Enam Bulan Pandemi, Angka Penularan Covid-19 Semakin Tinggi," 2020. https://www.beritasatu.com/kesehatan/67214 3/enam-bulan-pandemi-angka-penularancovid19-semakin-tinggi (accessed Jan. 14, 2021).

[2] P. Rizqiah, "Klasifikasi Komentar Twitter Tentang Pengesahan UUMD3 Menggunakan Metode Naïve Bayes," 2018.

[3] Yudianzer, "Menurun, Segini Jumlah Pengguna Twitter Sekarang - Pos Harian." https://yudianzer.blogspot.com/2016/12/men urun-segini-jumlah-pengguna-twitter.html (accessed Jan. 14, 2021).

[4] Y. Mardi, "Data Mining: Klasifikasi Menggunakan Algoritma C4.5," J. Edik Inform., vol. 2, no. 2, pp. 213-219, 2017.

[5] L. Y. T. Suarez, "Machine Learning Prediksi Karakter Pengguna Hastag (\#)," pp. 1-27, 2015.

[6] A. P. Wijaya and H. A. Santoso, "Naive Bayes Classification pada Klasifikasi Dokumen Untuk Identifikasi Konten EGovernment," J. Appl. Intell. Syst., vol. 1, no. 1, pp. 48-55, 2016, [Online]. Available: https://publikasi.dinus.ac.id/index.php/jais/is sue/view/76

A. T. J. Harjanta, A. Syukur, and C. Supriyanto, "Penerapan Pembobotan Atribut Pada Algoritma Naive Bayes Untuk Analisis Sentimen Review Aplikasi Android Dari Google Play," Jurnal Cyberku, vol. 11, no. April, pp. 78-89, 2015.

[8] F. S. Jumeilah, "Penerapan Support Vector Machine (SVM) untuk Pengkategorian Penelitian," J. RESTI (Rekayasa Sist. dan Teknol. Informasi), vol. 1, no. 1, pp. 19-25, 2017, doi: 10.29207/resti.v1i1.11.

[9] R. Ferdiana, F. Jatmiko, D. D. Purwanti, A. Sekar, T. Ayu, and W. F. Dicka, "Dataset Indonesia untuk Analisis Sentimen," Jurnal Nasional Teknik Elektro dan Teknologi Informasi (JNTETI), vol. 8, no. 4, pp. 334339, 2019.

[10] H. Najjichah, A. Syukur, and H. Subagyo, "Pengaruh Text Preprocessing Dan Kombinasinya," J. Teknol. Inf., vol. 15, no. 1, pp. 1-11, 2019.

[11] A. R. Nugraha and G. Pramukasari, "Sistem Informasi Akademik Sekolah Berbasis Web Di Sekolah Menengah Pertama Negeri 11 Tasikmalaya," J. Manaj. Inform., vol. 4, no. 2, pp. 1-10, 2017.

[12] R. P. Mahardikawati and Nurgiyatna, "Sistem Informasi Industri Kecil Menengah Pemerintahan Kabupaten Boyolali Berbasis Website," J. Tek. Inform (JUTIF), vol. 1, no. 2, pp. 53-60, 2020.

[13] S. Suryono, E. Utami, and E. T. Luthfi, "Klasifikasi Sentimen Pada Twitter Dengan Naive Bayes Classifier," Angkasa J. Ilm. Bid. Teknol., vol. 10, no. 1, pp. 89-96, 2018, doi: 10.28989/angkasa.v10i1.218.

[14] ICHI.PRO, "Streamlit - Merevolusi Pembuatan Aplikasi Data." https://ichi.pro/id/streamlit-merevolusipembuatan-aplikasi-data-248940993548562 (accessed Jan. 09, 2021).

[15] P. S. M. Suryani, L. Linawati, and K. O. Saputra, "Penggunaan Metode Naïve Bayes Classifier pada Analisis Sentimen Facebook Berbahasa Indonesia," Maj. Ilm. Teknol. Elektro, vol. 18, no. 1, pp. 145-148, 2019, doi: 10.24843/mite.2019.v18i01.p22.

[16] I. Sunni and D. H. Widyantoro, "Analisis Sentimen dan Ekstraksi Topik Penentu Sentimen pada Opini Terhadap Tokoh Publik," J. Sarj. Inst. Teknol. Bandung Bid. Tek. Elektro dan Inform., vol. 1, no. 2, pp. 200-206, 2012. 